\title{
Parameters of biological circulation of phytomass and nutritional elements in crop rotations
}

\author{
D.V. Litvinov ${ }^{1}$, A.O. Butenko ${ }^{2 *}$, V.I. Onychko ${ }^{2}$, T.O. Onychko ${ }^{2}$, L.V. Malynka ${ }^{3}$, I.M. Masyk ${ }^{2}$, L.M. Bondarieva ${ }^{2}$, \\ O.L. Ihnatieva ${ }^{2}$ \\ ${ }^{1}$ National University of life and environmental sciences of Ukraine, 03041, Kyiv Ukraine \\ ${ }^{2}$ Sumy National Agrarian University, Sumy, 160 H. Kondratieva Str., Ukraine \\ ${ }^{3}$ Vinnytsia National Agrarian University, Vinnytsia, Soniaczna St., Ukraine
}

E-mail: andb201727@ukr.net

Received: 26.08.2019. Accepted: 26.09.2019

\begin{abstract}
The research shows, that an increase of phytocoenoses provided an increase of phytomass volume in the biological cycle from 63.5 to $114.3 \mathrm{t} / \mathrm{ha}$. The yield of phytomass in a crop rotation, different in structure and set of crops, was as follows: for four-field and five-field crop rotation -63.5-86.7 t/ha, six field -89.4, seven-field -96.9, and eight-field $-114.3 \mathrm{t} / \mathrm{ha}$. The optimization of the ratio of grain, technical and fodder crops allowed us to regulate quantitative parameters of crops' phytomass, which was alienated from agrocoenosis. The yield of the main products, alienated from the field was, as follows: in four-field crop rotation $-20.7 \mathrm{t} / \mathrm{ha}$, fivefield -26.6, six-field -37.8 , seven field -28.4 and eight field $-41.3 \mathrm{t} / \mathrm{ha}$, which was $32.6 \%, 30.7 \%, 42.3 \%, 29.3 \%$ and $36.1 \%$, respectively. The rest returned to the soil with by-products and crop remains. The total amount of nutrients (NPK) in the phytomass, involved in the circulation, was within the range for four-field crop rotation ( $100 \%$ of grain crops) $-1,814 \mathrm{~kg} / \mathrm{ha}$, fivefield ( $80 \%$ grain and $20 \%$ technical) $-2,368 \mathrm{~kg} / \mathrm{hectare}$, six-field ( $66.8 \%$ of cereals, $33.2 \%$ of technical ones) $-2,599 \mathrm{~kg} / \mathrm{ha}$, seven-field ( $57.2 \%$ of cereals and $42.8 \%$ of technical) $-2,956 \mathrm{~kg} / \mathrm{ha}$, eight-field ( $62.5 \%$ of cereals, $25.0 \%$ of technical, $12.5 \%$ of fodder) -3.491 $\mathrm{kg} / \mathrm{ha}$.
\end{abstract}

Keywords: Crop rotation; Phytomass of crops; Biological circulation

\section{Introduction}

With aim of developing of the scientific development of scientifically substantiated methods of increasing the biological productivity of the soil is important for defining the parameters of the phytomass cycle and nutrition elements that are part of it. Due to the goal-seeking use of soil for growing agricultural products, it is necessary to take into account the content of organic matter and nutrients in the biological mass of the harvest as well as the balance of nutrients as one of the most important factors for the development of a specific (in contrast to the virgin areas growing) cultural process of soil formation and soil fertility formation (Aksenov, 2013; Petrenko, 1998; Ryan, 2017; Tanchik, 2009). The purpose of the researches was to establish quantitative indices of the phytomass and cycling of nutrient elements in different types of crop rotation on chernozem (Tsiuk, 2013).

The turn of phiromias of field crops and its elements is one of the effective factors in the development of a specific (unlike the virgin) cultural process of soil formation and the formation of soil fertility (Panchenko, 2016; Bomba, 2001).

In the technological approach to intensification of agriculture, the environment is mostly polluted with toxic substances, soil erosion is significantly spread, the species diversity of useful flora and fauna decreases significantly, and the danger of massive damage to agricultural crops by diseases and pests increases (Kvitko, 2003). Analysis of data on this subject indicates that the strategy of comprehensive intensification of agricultural systems is vulnerable. The resource and environmental constraints of such a strategy are becoming increasingly evident (Didur, 2019). The guarantee of obtaining ecologically pure and biologically valuable products is the introduction into the structure of crop areas of field, forage and special crop rotation of perennial legumes, solving due to them the problem of protein, the transfer of nitrogen in air to vegetable protein due to bacteria that fix nitrogen, enrichment of soil without entering mineral nitrogen fertilizers, biological loosening and soil texture by the root system of plants(Butenko, 2019; Gudz, 2014; Kolisnyk, 2019). One of the key tasks of agriculture is the search for ways to optimize the water regime of the soil, the use of those agrotechnical methods that reduce the productive losses of moisture, contribute to its accumulation and preservation due to precipitation in the autumn-winter and spring periods. Important role in regulating water and nutrient regime of crop rotation and systems of basic cultivation of soil (Sylina, 2008; Saiko, 2007; Radchenko, 2018; Palamarchuk, 2018). 
The effective impact of cultivation on the soil increases when the depth, methods and measures of it are carried out in a scientifically sound sequence and in close interaction with all the links of the agricultural system (Tsilurik, 2015).

\section{Material and methods}

The research was conducted in a long stationary experiment during 2015-2017 at the Panfilska research station of NSC "Institute of Agriculture of NAAS". Soil is typical, low-humus, shallow chernozem. Before conducting the test, the total content of humus in the arable layer was in the narrow range of values $3.15-3.18 \%$, mobile phosphorus $220-250 \mathrm{mg}$, and moving potassium $80-120 \mathrm{mg} / \mathrm{kg}$ of soil. The reaction of the soil solution is slightly alkaline, the degree of saturation of the soil-absorbing complex of the bases is high (85-90\%). When studying 4-8-field rotation of such crops like Winter wheat and Spring wheat, Spring barley, buckwheat, oats, corn for grain and green fodder, sugar beets, rape, sunflower, soybeans, peas (Table 1), were determined biomass of parts of field crops including their underground parts, content of basic nutrient elements and content of organic matter and nutrition elements, which alienated from the field with yield and enters the soil with post-harvest and root remains (Berdnikov, 2005; Yatsentiuk, 2010). The accounting of the main and by products of crops was carried out by weighing method during harvesting, accounting of post-harvest residues by the frame method in the triple repetition on the experimental plot, the mass of the roots by the generally accepted method in the same repetition (Armengot, 2016; Dospekhov, 1985; Caldiz, 2016; Huwe, 2002). Placement of plots was systematic according to the methodological recommendations, taking into account all trial methodology requirements by (Kyryliuk, 2013). Phenological monitoring of plants growth, development and biometric indices were determined during the main stages of organogenesis according with method of State Service for Rights Protection of Plant. The statistical processing of collected data was carried out according to dispersion method by using Statistica 6.0 and Microsoft Excel (Santín-Montanyá, 2016; Scherner, 2016; Titenko, 2010).

\section{Results and discussion}

In the system of crop rotation, when the crops in the fields interchange in time, the total phytomass depends not only on the level of the yield, but also on the set of crops in the crop rotation. According to the results of the research data were obtained for phytomass yield in crop rotation, different in structure and set of crops (Table 2.). In general, the amount of biomass in four-field crop rotation ( $100 \%$ saturated with grain crops) was in the range of $63.5 \mathrm{t} / \mathrm{ha}$, in five-field crop rotation $(80 \%$ of cereals and $20 \%$ of technical crops) $-86.7 \mathrm{t} / \mathrm{ha}$, of six ( $67 \%$ of cereals and $33 \%$ of technical ones) $-89.4 \mathrm{t} / \mathrm{ha}$, seven-field crop rotation ( $57 \%$ of cereals and $43 \%$ of technical crops) $-96.9 \mathrm{t} / \mathrm{ha}$, eight-field rotation ( $62.5 \%$ of cereals, $25 \%$ of technical and 12.5 fodder crops) $-114.3 \mathrm{t} / \mathrm{ha}$. From the obtained phytomass from the field, 32.6\%, 30.7, 42.3, 29.3 and $36.1 \%$ were alienated, respectively, the rest returned to the soil with plant remains.

Analyzing the parameters of the alienation of a part of the phytomass from its total circulation, separately in the crop rotation, it should be noted that in eight-field crop rotation (var. 9) 62.5\% saturated cereal spike cultures (Winter wheat and yarrow, Winter rye, barley and oats), $25 \%$ of technical (soy and sunflower) and $12.5 \%$ of fodder crops (corn on green feed), the amount of phytomass, which alienated from the circulation, amounted to $41.3 \mathrm{t} / \mathrm{ha}$ or $36.1 \%$. In six-field crop rotation (var. 6) where the proportion of grain crops was $67 \%$, and technical crops was $33 \%$, of which $16.7 \%$ occupy the sugar beets, the highest (42.3\%) relative index of alienation of phytomass from the general circulation was determined. That is, the introduction of sugar beet crop rotation, namely the widespread ratio of this crop, between the main (root crop) and the by-product (hybrid) production and the low incidence of biomass with root residues, has a significant influence on the parameters of the cycling of phytomass crop rotation in general.

Analyzing the four-field crop rotation on $100 \%$ saturated crops and five-way crop rotation, saturated with $80 \%$ and $20 \%$ technical crops (sunflower), similar in composition of grain crops, it should be noted that the expansion of the set of crops and their share in crop rotation has provided growth rates the total circulation of phytomass at $23.2 \mathrm{t} / \mathrm{ha}$, and the reduction of the part of alienation of phytomass by almost $2 \%$, compared with 4-crop rotation. Based on the obtained data on the release of dry matter of phytomass and chemical composition of plants parameters of biological and economic removal of nutrient elements of crops in different crop rotation are determined (Table 3 ). In four-field crop rotation for $100 \%$ saturation with grain crops, the total amount of nutrients involved in biological circle was $1814 \mathrm{~kg} / \mathrm{ha}$ (var. 3). With a yield of above-ground phytomass, $44 \%$ of the total amount of nutrients was alienated, and $56 \%$ remained in the soil, respectively. The circulation of field crops phytomass and nutritional elements is one of the efficient factors of development of a specific (as opposed to virgin) cultural process of soil formation and soil fertility formation. 
Table 1. Scheme of stationary experiment with investigation of crop rotation in terms of left-bank Forest-steppe- Panfylska research station of NSC "Institute of Agriculture NAAS".

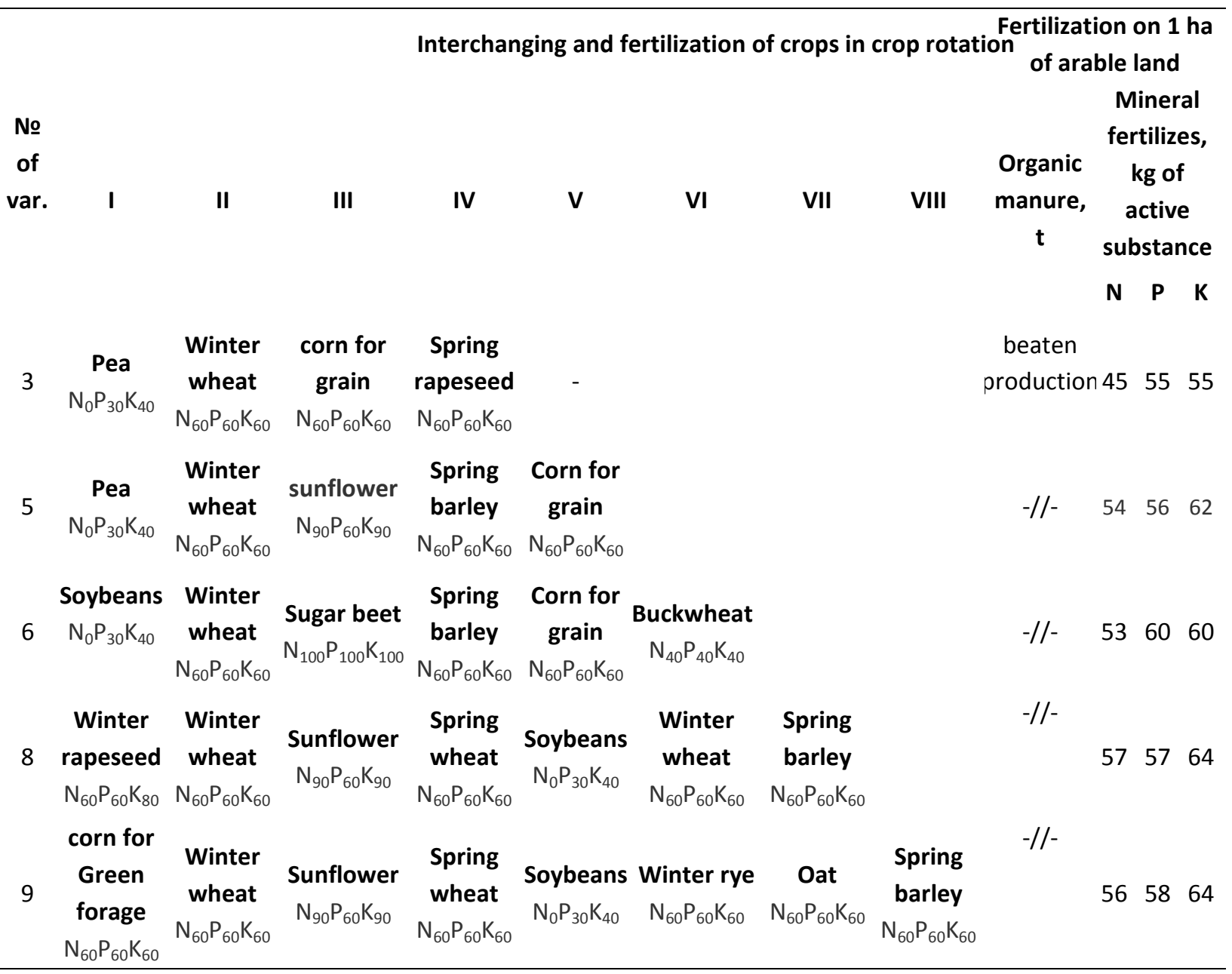

Note. ${ }^{*}$-It will be making of beaten manure in all predecessor crops.

In the case of growing legumes with cereals, the indicated effect of legumes on the soil is completely eliminated. Bean-cereal mixtures favorably influence the soil fertility, increasing the accumulation of organic matter in it, improving its structure, permeability, aeration (Prymak, 2017). At the same time, the turf of cereal-bean grass mixtures promotes the use of not only droplets of moisture, but also water vapor (sucking it as a sponge) (Provorov, 2013).

According to the results of the study, it was found that an increase in the species diversity of phytocoenoses provided an increase in the phytomass content of crops in the biological cycle from 63.5 to $114.3 \mathrm{t} /$ ha. The yield of phytomass in crop rotation, which differed in structure and crop set, was: for four-wheeled and five-wheeled crop rotation -63.5 ... $86.7 \mathrm{t} / \mathrm{ha}$, six-crop $-89.4 \mathrm{t} / \mathrm{ha}$, semi-fodder - $96.9 \mathrm{t} / \mathrm{ha}$, octopus - $114.3 \mathrm{t} / \mathrm{ha}$. Optimization of the ratio of crop rotation of grains, technical and forage crops allowed to regulate the quantitative parameters of phytomass of agricultural crops alienated from agrocenosis.

It was investigated that the yield of the main products from the field was alienated in four-wheeled crop rotation $-20.7 \mathrm{t} / \mathrm{ha}$, fivefold $-26.6 \mathrm{t} / \mathrm{ha}$, six-tern $-37.8 \mathrm{t} / \mathrm{ha}$, semifurnal $-28.4 \mathrm{t} / \mathrm{ha}$ and octopus $-41.3 \mathrm{t} / \mathrm{ha}$, which in relative terms was $32.6 \%, 30.7 \%$, $42.3 \%, 29.3$ and $36.1 \%$, respectively, the rest returned to the soil with by-products and poplars.

The total amount of nutrients (NPK) in the phytomass, which was involved in the colloid, was within the limits for four-wheeled crop rotation ( $100 \%$ of grain crops) $-1814 \mathrm{~kg} / \mathrm{ha}$, five-grain ( $80 \%$ of cereals and $20 \%$ of technical) $-2368 \mathrm{~kg} / \mathrm{hectare}, \mathrm{six}-(66.8 \%$ of grain, $33.2 \%$ of technical) $-2599 \mathrm{~kg} / \mathrm{ha}, 7$-field crop rotation $(57.2 \%$ of cereals and $42.8 \%$ of technical) $-2956 \mathrm{~kg} / \mathrm{ha}, 8$-field crop rotation ( $62.5 \%$ of cereals, $25.0 \%$ of technical, $12.5 \%$ of feed) $-3491 \mathrm{~kg} / \mathrm{ha}$. It was established that, depending on the structure of crop rotation, the yield of phytomass from the field was alienated from 1020 to $1738 \mathrm{~kg} / \mathrm{ha} \mathrm{NPK}$.

Increasing the rotation of crop rotation to 5 fields ( $80 \%$ of cereals and $20 \%$ of technical), an increase in the total number of nutrition elements in the circle of $30 \%$, compared to four-field crop rotation, to $2368 \mathrm{~kg} / \mathrm{ha}$ (var 5). It was also found that in fivefield crop rotation with $80 \%$ saturation of cereals and $20 \%$ saturation of technical crops, the average share of NPK in plant remains was $57 \%$ in the experiment. 


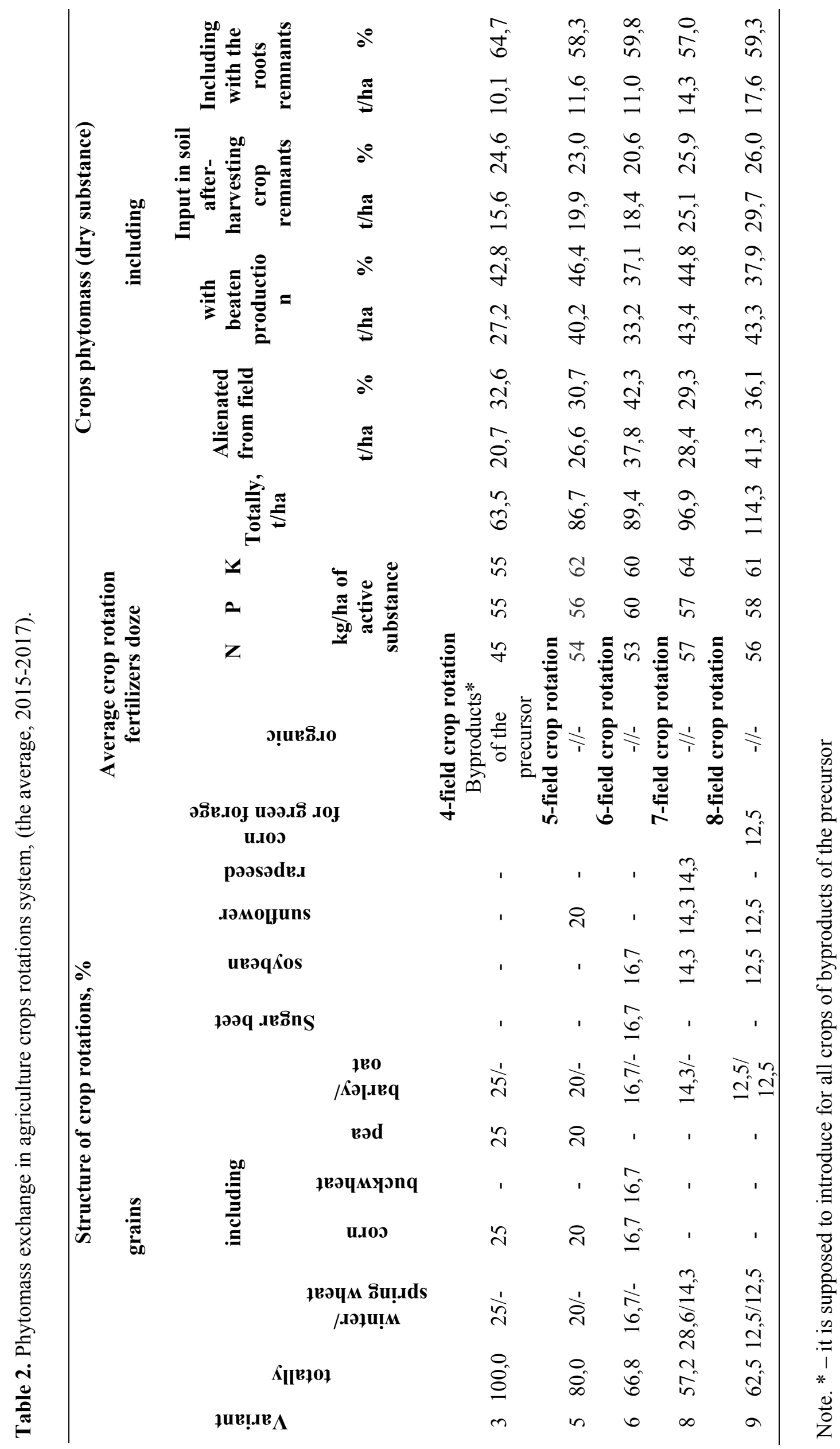




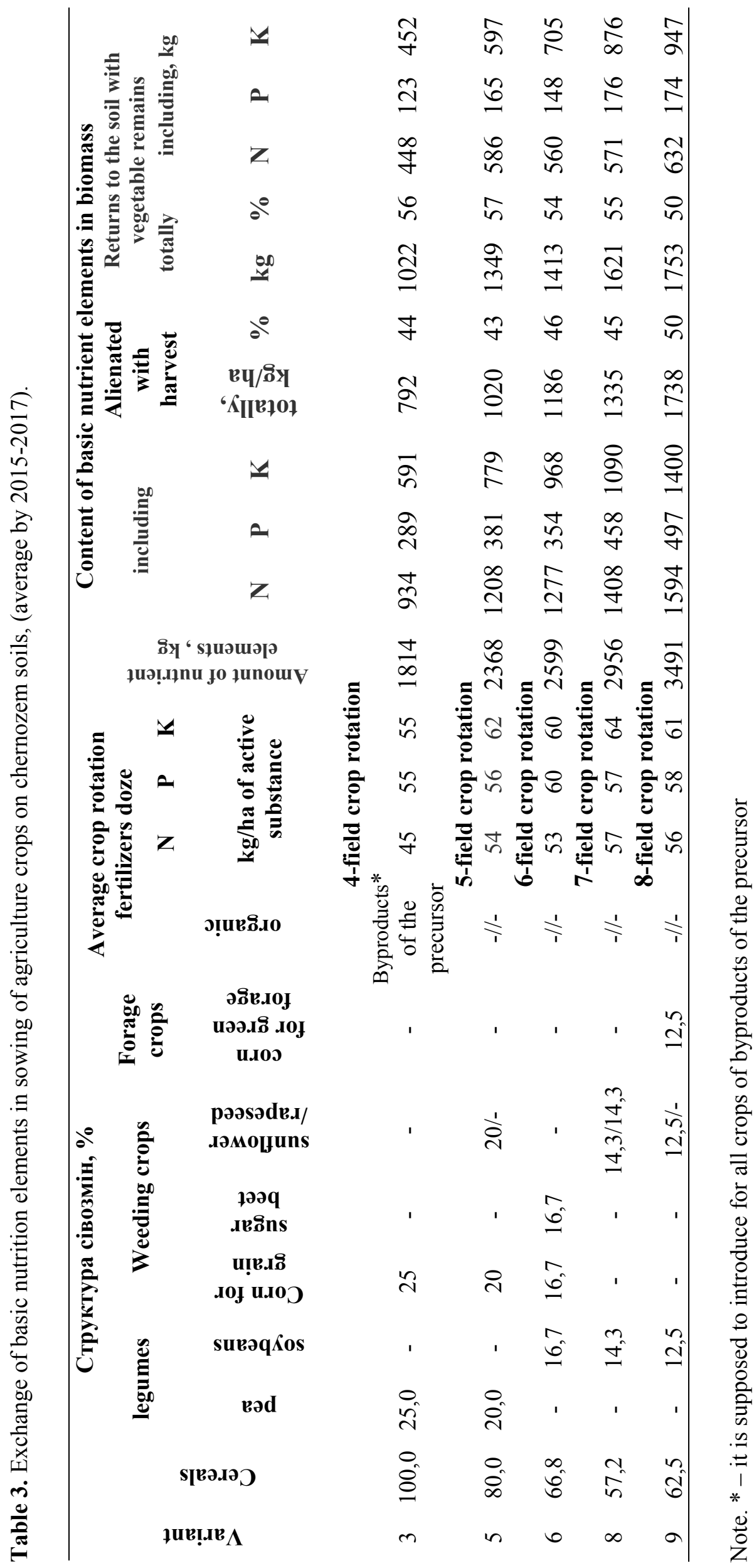


In the six-field crop rotation (var. 6), the total NPK in biomass was $2599 \mathrm{~kg} / \mathrm{ha}$, the yield of $1186 \mathrm{~kg} / \mathrm{ha}$ (46\%) was alienated, and $1413 \mathrm{~kg} / \mathrm{h}$ a or $54 \%$ was returned to the soil with vegetable residues, including N -560, P-148 and K-705 kg/ha. In the seven-field crop rotation (var. 8), the lowest part of grain crops (57\%) was the alienation of nutrients with a yield of basic products of 1335 $\mathrm{kg} / \mathrm{ha}$, while the level of return to the soil with vegetable remains was $1621 \mathrm{~kg} / \mathrm{ha}$ or $55 \%$. The introduction of corn on the green fodder ( var 9) into the structure of eight-field crop rotation increased the parameters of the removal of NPK with a yield of the main products to $1738 \mathrm{~kg} / \mathrm{ha}$ and a decrease in the level of supply of nutrients to the soil with plant remains to $1753 \mathrm{~kg}$, or $50 \%$ of the total cycle of nutrition elements. With the increase in the structure of crop rotation of the proportion of such crops as corn and sunflower, the total amount of nutrients in phytomass increased, while for the introduction of grain crop rotation of sugar beet and maize into green fodder, the proportion of the phytomass cycle that was alienated from the field grew.

\section{Conclusion}

It is established that in the system of diversified crop rotation, the total phytomass of plants, as well as the amount of nutrients that are part of it, is determined not only by the level of productivity of the main and by-products of crops, but also largely by the structure and set of crops in the crop rotation. Given the need to evaluate the crop rotation not only in terms of output but also in terms of the quantity and quality of plant residues entering the soil as a source of compensation for humus losses, among the studied options, priority is given to crop rotation in $80 \%$ of saturated crops (incl. $20 \%$ corn for grain) and $20 \%$ technical (sunflower): the yield of biomass as well as its amount returning to the soil with plant residues, including those with roots, was $57 \%$, and the share that alienates the smallest among the studied crop rotations is $43 \%$.

\section{References}

Aksenov I. V., Gavrilyuk Yu.V. (2013). The influence of the main tillage on the agrophysical properties of the soil and the contamination of crops of crop rotation under the conditions of the Steppe of Ukraine. Bulletin of the Belarusian State Agricultural Academy, 3, 81-85.

Petrenko L.R., Andrienko, V.A., Ridei N.M. (1998). Changes in soil biological properties when applying tillage without turning over the soil layer. Restoration of soil fertility in soil-protective agriculture, 122-144.

Ryan. (2017). Timing of tillage as a driver of weed communities. Weed Science, 65(4), 504-514.

Tanchik S.P. (2009). Efficiency of farming systems in Ukraine. Bulletin of Agrarian Science, 12, 5-11.

Tsiuk, O.A. (2013). The theoretical rationale and development of the ecological farming system in the forest-steppe zone of Ukraine: abstract of the dissertation for a degree of the Candidate of Agricultural Sciences: spec. 06.01.01 "General Farming", 41.

Panchenko, O.B. (2016). Restoration of soil fertility of typical chernozem depending on the systems of primary tillage and fertilization in the tilled crop rotation of the Right-bank forest-steppe zone of Ukraine: abstract of the dissertation for a degree of the Candidate of Agricultural Sciences: spec. 06.01.01 "General Farming", 22.

Bomba M., Kovalchuk Y. (2001). Complex influence of tillage and fertilization upon acidity and biological activity of Ukraine grey forest soils. III Scientific Conference, Natural and anthropogenic causes and effects of soil acidification, Lublin, p. 50.

Kvitko, H.P., Hetman, N.Y. (2003). Nitrogen fixing capacity and soil enrichment with nitrogen depending on the lifetime of Medicago sativa in conditions of forest-steppe. Forage and Fodder Production, 51, 54-57.

Didur, I.M., Tsyhanskyi, V.I., Tsyhanska, O.I., Malynka, L.V., Butenko, A.O., Klochkova, T.I. (2019). The effect of fertilizer system on soybean productivity in the conditions of right bank forest-steppe. Ukrainian Journal of Ecology, 9(1), 76-80.

Butenko, A.O., Sobko, M.G., Ilchenko, V.O., Radchenko, M.V., Hlupak, Z.I., Danylchenko, L.M., Tykhonova, O.M. (2019). Agrobiological and ecological bases of productivity increase and genetic potential implementation of new buckwheat cultivars in the conditions of the Northeastern Forest-Steppe of Ukraine. Ukrainian Journal of Ecology, 9(1), 162-168.

Gudz, V.P. (2014). Adaptive farming systems, Center for Educational Literature, Kyiv, 336.

Kolisnyk, O.M., Butenko, A.O., Malynka, L.V., Masik, I.M., Onychko, V.I., Onychko, T.O., Kriuchko, L.V., Kobzhev, O.M. (2019). Adaptive properties of maize forms for improvement in the ecological status of fields. Ukrainian Journal of Ecology, 9(2), 33-37.

Sylina, L.I., Hryncuk, P.D., Jermolajev, M.M., Litvinov, D.V. (2008). Basic programmatic questions and methodical recommendations for the study of crop rotation in stationary experiments. Kyiv, 32.

Saiko, V.F. (2007). Soil cultivation systems in Ukraine. Kyiv: VD "EKMO", 44.

Radchenko, M.V., Butenko, A.O., Glupak, Z.I. (2018). Effect of fertilizer system and efficiency of growth regulator on buckwheat productivity in the conditions of the northeastern forest-steppe of Ukraine. Ukrainian Journal of Ecology, 8(2), 89-94.

Palamarchuk, V., Telekalo, N. (2018). The effect of seed size and seeding depth on the components of maize yield structure. Bulgarian Journal of Agricultural Science. 24, 783-790.

Tsilurik, O.I. (2015). Productivity of crotation crop rotation depending on the system of cultivating soil on the background of continuous mulching by postbreaks. Bulletin of the Institute of Agriculture of the steppe zone, 8, 66-72. 
Prymak, I.D., Panchenko, O.B., Panchenko, I.A. (2017). Enzyme activity of typical chernozem when applying different systems of tillage and fertilization of crops in the specialized tilled crop rotation. Bulletin of Lviv National Agrarian University, 21, 30-37.

Provorov, N.A. (2013). Increase of efficiency of the nitrogen symbiotic fixing by plants: Molecular-genetic approaches and evolutional models. Physiology of plants, 60, 31-37.

Berdnikov, A.M., Patyka, N.V., Sytnik, S.A. (2005). The rational use of biological and mineral nitrogen in Polesye agriculture. Agroyekologichniy Zhurnal, 2, 14-20.

Yatsentiuk, R.V. (2010). Liming of sour soils: basis of their fertility increase. Ahronom, 3, 168-169.

Armengot, L., Blanco-Moreno, J.M., Bàrberi, P., Bocci G., Carlesi, S., Aendekerk, R., Berner A., Celette, F., Grosse, M., Huiting, H. ,Kranzler, A., Luik, A., Mäder, P., Peigné, J., Stoll, E., Delfosse, P., Sukkel, W., Surböck, A., Westaway, S., Sans, F.X. (2016). Tillage as a driver of change in weed communities: a functional perspective. Agriculture, Ecosystems \& Environment, 222, 276-285.

Dospekhov, B.A. (1985). The methodology of field experiment (with the basics of statistical processing of research results). 5th revised and enlarged edition. M.: Agropromizdat, 351.

Caldiz, D.O., de Lasa, C., Bisio, P.E. (2016). Management of Grass and Broadleaf Weeds in Processing Potatoes (Solanum tuberosum L.) with Clomazone, in the Argentinian Pampas. American Journal of Plant Sciences, 07(16), 2339-2348.

Huwe, B. (2002). The role of soil tillage for soil structure. Soil tillage in agroecosystems.

Kyryliuk, V.P. (2013). The influence of long-term use of systems of the basic soil cultivation on the weediness of crop rotation. Podillian state agrarian and engineering university collection, 21, 39-43

Santín-Montanyá, M.I., Martín-Lammerding, D., Zambrana, E., Tenorio, J.L. (2016). Management of weed emergence and weed seed bank in response to different tillage, cropping systems and selected soil properties.Soil and Tillage Research, 161, 38-46.

Scherner, A., Melander, B., Kudsk, P. (2016). Vertical distribution and composition of weed seeds within the plough layer after eleven years of contrasting crop rotation and tillage schemes. Soil and Tillage Research, 3, 161:135.

Titenko, A.O. (2010). Influence of tillage soil in link with intermediate crop of on weed infestation of Spring barley sowings after stubbles forecrop. Premountain and mountain agriculture and stock-breeding, 52(2), 79-86.

Citation: Litvinov, D.V., Butenko, A.O., Onychko, V.I., Onychko, T.O., Malynka, L.V., Masyk, I.M., Bondarieva, L.M., Ihnatieva, O.L. (2019). Parameters of biological circulation of phytomass and nutritional elements in crop rotations. Ukrainian Journal of Ecology, 9(3), 92-98.

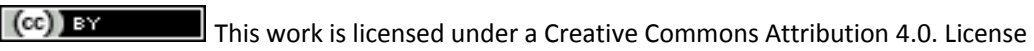

